\title{
Evaluating Grafted Watermelon for Verticillium Wilt Severity, Yield, and Fruit Quality in Washington State
}

\section{Jesse Wimer}

Department of Horticulture, Northwestern Washington Research and Extension Center, Washington State University, Mount Vernon, WA 98273

\author{
Debra Inglis \\ Department of Plant Pathology, Northwestern Washington Research and \\ Extension Center, Washington State University, Mount Vernon, WA 98273
}

\section{Carol Miles ${ }^{1}$}

Department of Horticulture, Northwestern Washington Research and Extension Center, Washington State University, Mount Vernon, WA 98273

Additional index words. Verticillium dahliae, rootstocks, total soluble solids, lycopene content, firmness

\begin{abstract}
Verticillium wilt caused by Verticillium dahliae is a serious disease for watermelon growers in Washington State. Grafting represents a possible alternative disease management strategy, but little is known about rootstock resistance to verticillium wilt or the performance of grafted watermelon in the different production regions of the state. In this study, verticillium wilt severity, yield, and fruit quality were evaluated at three contrasting field sites in Washington using verticillium wilt-susceptible 'Sugar Baby' (diploid) watermelon grafted onto four commercial rootstock cultivars (Marvel, Rampart, Tetsukabuto, and Titan); nongrafted 'Sugar Baby' was included as the control. Verticillium dahliae soil densities varied at each site $(<1.0,5.7$, and 18.0 colony-forming units (cfu)/g soil at Othello, Eltopia, and Mount Vernon, respectively). Area under disease progress curve (AUDPC) values differed significantly among treatments at Eltopia and Mount Vernon. Nongrafted 'Sugar Baby' had the highest AUDPC value at all three sites, while 'Sugar Baby' grafted onto 'Tetsukabuto' had the lowest AUDPC value at Eltopia and Mount Vernon. Nongrafted 'Sugar Baby' also had the lowest fruit weight per plant at all sites, but 'Sugar Baby' grafted onto 'Tetsukabuto' had the highest fruit weight per plant at Eltopia and Mount Vernon. Marketable fruit weight per plant did not differ among treatments at Othello. Yield was negatively correlated with AUDPC values at both Eltopia and Mount Vernon. Fruit number per plant was only significantly impacted at Eltopia, where 'Sugar Baby' grafted onto 'Tetsukabuto' had more fruit per plant than all other treatments except 'Sugar Baby' grafted onto 'Rampart'. Fruit quality (flesh firmness, total soluble solids, and lycopene content) was unaffected by grafting at either Othello or Eltopia, except for increased flesh firmness for 'Sugar Baby' grafted onto 'Marvel' and 'Titan' as compared with nongrafted 'Sugar Baby' at Eltopia. At season's end, plants were sampled from all treatments at Eltopia and Mount Vernon and assayed for $\boldsymbol{V}$. dahliae. Microsclerotia typical of this organism were observed in all samples. Results from this study indicate that verticillium wilt of watermelon can be successfully managed by grafting when the $V$. dahliae soil density exceeds $5.0 \mathrm{cfu} / \mathrm{g}$ in Washington. In addition, grafting does not reduce fruit quality and using certain rootstocks can improve the quality of flesh firmness at certain locations.
\end{abstract}

Verticillium wilt caused by the soilborne fungus $V$. dahliae is a significant disease affecting watermelon (Citrullus lanatus) production in Washington State (Dung and Weiland, 2014; Sunseri and Johnson, 2001). Once established in the field, $V$. dahliae is extremely difficult to manage due to its wide host range and longlived resting structures called microsclerotia (Berlanger and Powelson, 2000; Tjamos, 1989). Microsclerotia in the soil germinate

Received for publication 14 May 2015. Accepted for publication 13 July 2015 .

${ }^{1}$ Corresponding author. E-mail: milesc@wsu.edu. and invade the roots of host plants. The pathogen ultimately colonizes the xylem of its host, thereby disrupting the transpiration stream and leading to the characteristic symptoms of chlorosis, necrosis, and wilting (Fradin and Thomma, 2006; Klosterman et al., 2009). Traditionally, preplant soil fumigation has been used to manage $V$. dahliae; however, currently available fumigants (e.g., metam sodium) are not always reliable (Davis et al., 2008b; Klosterman et al., 2009; Woodward et al., 2011). Thus, alternative strategies are needed to achieve successful management of this pathogen.

Many researchers have demonstrated that grafting can reduce soilborne disease severity of watermelon (King et al., 2008; Louws et al., 2010). While fusarium wilt (caused by Fusarium oxysporum) has been the primary focus of watermelon grafting research, some studies have explored the potential of grafting to control verticillium wilt. Paplomatas et al. (2000) screened 33 cucurbit rootstocks for verticillium wilt resistance and found many to be tolerant, although none were completely resistant. A comparable study conducted by Wimer et al. (2014) generated similar results. Paplomatas et al. (2002) showed that grafting watermelon onto disease-tolerant rootstocks could delay symptom onset by nearly 3 weeks, thus allowing sufficient time for crop maturation. Paroussi et al. (2007) observed decreased verticillium wilt incidence on grafted watermelon plants grown in artificially inoculated soil, and Buller et al. (2013) observed reduced verticillium wilt severity of grafted watermelon plants at a naturally infested field site with a relatively high $V$. dahliae soil density. While these results appear promising, growers in Washington are unlikely to adopt grafting as a verticillium wilt management strategy until its efficacy has been more thoroughly demonstrated.

The conflicting reports in the literature regarding the effects of grafting on watermelon fruit flavor, yield, and quality also present a barrier to the adoption of this practice. Davis et al. (2008b) reported that sometimes an "insipid flavor" is associated with grafted watermelon; however, this may be due to harvesting fruit prematurely, as grafting can sometimes delay maturity. Buller et al. (2013), Bekhradi et al. (2011), and Miguel et al. (2004) reported no significant changes in total soluble solids (TSS), lycopene content, fruit firmness, fruit diameter, or fruit weight as a result of grafting, while Turhan et al. (2012) and Lopez-Galarza et al. (2004) observed a decrease in TSS as a result of grafting. In contrast, many researchers have observed positive effects on fruit yield and quality as a result of grafting, including increased lycopene content, flesh firmness, and fruit weight (Lee et al., 2010; Proietti et al., 2008; Salam et al., 2002; Taylor et al., 2006). Two primary factors that account for the variable effects of grafting on fruit yield and quality are rootstock species/cultivar and environmental conditions (Davis et al. 2008a). For instance, Yetişir et al. (2003) observed decreased yield when certain Cucurbita rootstocks were used, while Bruton et al. (2009) found that flesh firmness was significantly increased by the use of interspecific hybrid squash rootstocks but not bottle gourd rootstocks. Petropoulos et al. (2012) found that TSS was significantly impacted by rootstock-scion combinations. Louws et al. (2010) reported that diseaseresistant rootstocks can sometimes decrease yield when certain pathogens are not present, highlighting the need for thorough identification and quantification of pathogen populations in the soil.

Of the factors that influence the performance of grafted watermelon, rootstock 
cultivar/species is perhaps the easiest for the grower to manipulate. There are currently many available watermelon rootstock cultivars on the market; thus, special regard must be taken to select ones that are not only suitable for regional growing environments (including climate and pathogen density), but that also provide sufficient disease management without negatively impacting fruit yield or quality. As of yet, grafted watermelon across Washington's diverse growing regions. Thus, the objective of this study was to determine the effects (if any) of various rootstock cultivars on verticillium wilt severity, yield, and fruit quality of grafted watermelon plants at three differing locations in Washington State.

\section{Materials and Methods}

Experimental conditions. This study was conducted at three contrasting locations in Washington State during the 2014 field season (Table 1). Two of the field sites were located on commercial watermelon farms in the Columbia Basin of eastern Washington near Eltopia and Othello, where the summer climate is hot and dry. The third site was located in the Skagit Valley at Washington State University (WSU) Mount Vernon, where the summers are cooler and more humid. At each site, at transplanting, 20 soil samples were taken randomly within the experimental plots to a depth of $15 \mathrm{~cm}$, and the $V$. dahliae soil density was determined using a technique modified from Butterfield and DeVay (1977).

Plant material, plot establishment, and field maintenance. There were five treatments included in this study: nongrafted verticillium wilt-susceptible 'Sugar Baby' watermelon (C. lanatus; diploid) and 'Sugar Baby' grafted onto the commercial rootstocks 'Marvel' (Cucurbita moschata), 'Rampart' (Lagenaria siceraria), 'Tetsukabuto' (Cucurbita maxima $\times$ C. moschata), and 'Titan' (Cucurbita hybrid). All plant material was propagated from seed at WSU plants have not been thoroughly evaluated

Mount Vernon. The target transplanting date for Eltopia and Othello was 10 May; thus, 'Sugar Baby' was sown on 26 Mar., followed by 'Rampart' on 31 Mar., and 'Marvel', 'Tetsukabuto', and 'Titan' on 4 Apr. Grafting occurred on 12 Apr. using the one-cotyledon splice technique when both scion and rootstock plants were at the early true first leaf stage. The grafted seedlings were then placed in a healing chamber to facilitate graft union formation (Miles et al., 2013). All transplants were transported to their respective field sites on 6 May for acclimation, when plants reached the 2-3 true-leaf growth stage. Transplanting into plastic-covered raised beds ( $0.9 \mathrm{~m}$ in-row spacing) occurred on 8 and 13 May at Othello and Eltopia, respectively. At Othello, beds were $2.3 \mathrm{~m}$ center-tocenter, while at Eltopia bed spacing was $1.4 \mathrm{~m}$ center-to-center. At both sites, water was applied via drip irrigation at a rate of $50 \mathrm{~mm}$ per week throughout the growing season. The target transplanting date for Mount Vernon was 15 June; thus, 'Sugar Baby' was sown on 13 May, followed by 'Rampart' on 19 May, and 'Marvel', 'Tetsukabuto', and 'Titan' on 23 May. Grafting occurred on 2 June using the hole-insertion technique (because of a large size difference between the rootstocks and scion) when both scion and rootstock plants were at the early first true leaf stage (Miles et al., 2013). The grafted seedlings were then placed in a healing chamber to facilitate graft union formation following the procedures used above. Transplanting into plastic-covered raised beds $(0.9 \mathrm{~m}$ in-row spacing, $3 \mathrm{~m}$ center-tocenter) occurred on 19 June, when plants were at the 2-3 true-leaf stage. Drip irrigation was applied at a rate of $25 \mathrm{~mm}$ of water through July and every 3 weeks thereafter for the remainder of the growing season. Field sites were not fumigated, and no other pesticides were applied to the plot areas.

Verticillium wilt ratings. Verticillium wilt severity was rated visually at all sites and was recorded as the percent of the plot canopy displaying characteristic symptoms (chlorosis, necrosis, and wilting) (Dung and Johnson,

Table 1. Location, environmental conditions, and cropping history at the study sites near Othello, Eltopia, and Mount Vernon, WA, in 2014

\begin{tabular}{lccc}
\hline & Othello & Eltopia & Mount Vernon \\
\hline Latitude & $46^{\circ} 52^{\prime} 32.21^{\prime \prime} \mathrm{N}$ & $46^{\circ} 29^{\prime} 23.41^{\prime \prime} \mathrm{N}$ & $48^{\circ} 26^{\prime} 23.09^{\prime \prime} \mathrm{N}$ \\
Longitude & $119^{\circ} 28^{\prime} 29.62^{\prime \prime} \mathrm{W}$ & $119^{\circ} 11^{\prime} 10.54^{\prime \prime} \mathrm{W}$ & $122^{\circ} 23^{\prime} 44.04^{\prime \prime} \mathrm{W}$ \\
Elevation $(\mathrm{m})$ & 316 & 260 & 6 \\
Avg temp $\left({ }^{\circ} \mathrm{C}\right)^{\mathrm{z}}$ & 20 & 21 & 18 \\
Avg min temp $\left({ }^{\circ} \mathrm{C}\right)$ & 13 & 12 & 12 \\
Avg max temp $\left({ }^{\circ} \mathrm{C}\right)$ & 28 & 30 & 24 \\
Avg $\mathrm{RH}(\%)$ & 53 & 56 & 82 \\
Total precipitation $(\mathrm{mm})$ & 24 & 8 & 104 \\
$V$. dahliae density & $<1.0$ & 5.7 & 18.0 \\
Soil type $^{\mathrm{x}}$ & Ephrata fine & Tauncal very fine & Skagit silt loam \\
& sandy loam & sandy loam & Mixed cucurbits \\
Cropping history $^{\mathrm{w}}$ & Alfalfa & Melons & M
\end{tabular}

${ }^{2}$ Weather data were obtained via Washington State University AgWeatherNet stations (Washington State University, 2014) located near the field sites.

${ }^{\mathrm{y}}$ Verticillium dahliae soil density was measured in colony-forming units per gram of soil.

'Soil types were determined using the University of California's SoilWeb: online soil survey browser (2010). 29 Apr. 2014. <http://calsoilresource.lawr.ucdavis.edu/>.

${ }^{\mathrm{w}} \mathrm{Crop}$ that was planted in the preceding year in the same field as the study.
2012). These ratings were initiated at symptom onset and recorded at Othello on 49, 61, 69, and $76 \mathrm{~d}$ after transplanting (DAT), at Eltopia on 44, 56, 64, and 71 DAT, and at Mount Vernon on 42, 49, 56, 63, and 70 DAT. The disease severities (percentages) were plotted over time and the AUDPC value was calculated for each treatment at each site. At season's end the most severely wilted plant from each plot at Eltopia (26 Aug.) and Mount Vernon (18 Sept.) was assayed for Verticillium spp., while plants were not sampled at Othello due to early removal of the crop by the farmer. Plants were cut at the soil line and then cut again to attain a $20 \mathrm{~cm}$ stem sample that included the graft union. Samples were surface sterilized using a $10 \%$ bleach solution and rinsed with deionized (DI) water. Each sample was then cut in half longitudinally to expose the vascular tissue and incubated in a plastic container. After 4 weeks, the samples were examined for the presence of microsclerotia using a dissecting microscope $(\times 40)$.

Measuring fruit yield and quality. At Othello and Eltopia, fruit were harvested as they ripened, which was determined by the complete drying and browning of the tendril nearest the fruit. Fruit were harvested at Othello on $69,76,82$, and 89 DAT and at Eltopia on $64,71,77$, and 84 DAT. The number of marketable fruit and weight of marketable fruit per plant were recorded for each plot at both sites. Fruit were determined unmarketable if they had excessive insect damage, disease, scarring, or if the fruit was misshapen. Fruit did not reach maturity at Mount Vernon due to the cool, short growing season and late transplanting date; however, at season's end (85 DAT) all nearly mature fruit $(>2 \mathrm{~kg})$ were harvested and the number and weight of these fruit per plant were recorded.

For each harvest date at Othello and Eltopia, three marketable fruit were arbitrarily selected from each plot for fruit quality testing, and data for each treatment were pooled for all harvest dates. These fruit were cut in half along the longitudinal axis and a $5-\mathrm{cm}^{3}$ sample was taken just off center near the blossom end. Flesh firmness (newton, or N) was measured to a depth of $1 \mathrm{~cm}$ using a drillpress penetrometer (Ametek, Berwyn, PA) fixed with a $4 \mathrm{~mm}$ cylindrical blunt-end tip. The three firmness measurements for each plot were averaged, resulting in three data points for each treatment at each site for each harvest date. The TSS of the juice was measured using a Palm Abbe ${ }^{\mathrm{TM}}$ refractometer (MISCO, Cleveland, OH). After the instrument was calibrated with DI water, $1 \mathrm{ml}$ of juice from each fruit sample was placed on the measuring surface. Following the reading, the instrument was cleaned with DI water before the next sample was loaded. As with firmness, the three TSS readings for each plot were averaged.

Lycopene content was determined using a spectrophotometer protocol modified from Nagata \& Yamashita (1992). For each plot, sections of flesh measuring $\approx 3 \mathrm{~cm}^{3}$ were removed from each of the three fruit, 
combined to make one composite sample, and frozen at $-20{ }^{\circ} \mathrm{C}$. Frozen samples were homogenized using a mortar and pestle. A 1-g subsample was taken from each homogenized sample and placed in $16 \mathrm{~mL}$ of a chilled acetone:hexane (2:3) mixture. The supernatant from each sample was extracted and placed in a cuvette. The cuvettes were loaded into a Beckman DU-65 spectrophotometer (Beckman Coulter, Inc., Brea, CA) and absorbance readings were taken at 453, 505, 645, and $663 \mathrm{~nm}$.

Experimental design and statistical analysis. The experiment at each site was arranged as a randomized complete block design with three replications and six plants per plot. Data were analyzed using PROC GLM in SAS (version 9.2; SAS Institute, Cary, NC) with $\alpha=0.05$, and a correlation analysis for yield and AUDPC at each site was conducted using PROC CORR. The AUDPC data from all sites, and fruit weight and fruit number data from Mount Vernon required transformation for statistical analysis. Using the range method outlined by Kirk (1982), the rank transformation was deemed most appropriate in all cases. Data were ranked using PROC RANK in SAS. Due to differences in planting dates, soil types, climate, $V$. dahliae soil densities, and cultural practices, all sites were analyzed separately. Significant differences between treatment means were compared using Fisher's least significant difference test with $\alpha=0.05$.

\section{Results}

Verticillium wilt severity. Verticillium wilt symptoms were observed in all treatments at all sites; and at each site, symptom onset occurred at the same time for all treatments, although disease severity differed among treatments. At Othello, the AUDPC values ranged from 22.7 ('Sugar Baby' grafted onto 'Marvel') to 154.0 (non-grafted 'Sugar Baby'), but ratings did not differ among treatments $(P=0.59)$ (Table 2). At Eltopia, AUDPC values differed among treatments $(P=0.05)$. Non-grafted 'Sugar Baby' had the highest value (361.7) at this site but did not differ from 'Sugar Baby' grafted onto 'Marvel' and 'Titan' (137.7 and 243.7, respectively). 'Sugar Baby' grafted onto 'Tetsukabuto' and 'Rampart' had the lowest AUDPC values (17.3 and 76.7, respectively). At Mount Vernon, the AUDPC values also differed among treatments $(P=$ 0.0006). Non-grafted 'Sugar Baby' had a higher value (502.4) than all other treatments at this site and 'Sugar Baby' grafted onto 'Tetsukabuto' had a lower value (24.1) than all other treatments. Microsclerotia typical of Verticillium spp. were observed on the incubated stem samples of all treatments at Eltopia and Mount Vernon.

Fruit yield and quality. At Othello, there was no difference in marketable fruit weight per plant among entries $(P=0.07)$ (Fig. 1). The overall mean was $14.30 \mathrm{~kg}$ at this site and ranged from $11.86 \mathrm{~kg}$ (nongrafted 'Sugar Baby) to $17.80 \mathrm{~kg}$ ('Sugar Baby' grafted onto 'Titan'). At Eltopia, differences in

Table 2. Area under disease progress curve (AUDPC) values for severity of verticillium wilt symptoms on non-grafted verticillium wilt-susceptible 'Sugar Baby' watermelon, and 'Sugar Baby' grafted onto the commercial rootstocks 'Marvel', 'Rampart', 'Tetsukabuto', and 'Titan' at Othello, Eltopia, and Mount Vernon, WA, where the Verticillium dahliae populations were $<1.0,5.7$, and 18.0 colony-forming units per gram of soil, respectively, in 2014.

\begin{tabular}{lccr}
\hline & \multicolumn{3}{c}{ AUDPC values $^{\mathrm{z}}$} \\
\cline { 2 - 4 } Treatment $^{\mathrm{y}}$ & Othello & Eltopia & Mount Vernon \\
\hline Sugar Baby & 154.0 & $361.7 \mathrm{a}$ & $502.4 \mathrm{a}$ \\
SB (Marvel) & 22.7 & $137.7 \mathrm{abc}$ & $96.5 \mathrm{~b}$ \\
SB (Rampart) & 75.2 & $76.7 \mathrm{bc}$ & $113.8 \mathrm{~b}$ \\
SB (Tetsukabuto) & 133.3 & $17.3 \mathrm{c}$ & $24.1 \mathrm{c}$ \\
SB (Titan) & 62.0 & $243.7 \mathrm{ab}$ & $87.9 \mathrm{~b}$ \\
$P$ value $^{\mathrm{x}}$ & 0.59 & 0.05 & 0.0006 \\
\hline
\end{tabular}

${ }^{z}$ Disease severity was recorded as the percent of the plot canopy displaying verticillium wilt symptoms (chlorosis, necrosis, and wilting). Mean area under disease progress curve (AUDPC) values were calculated based on verticillium wilt severity visual assessments taken on four rating dates at Othello and Eltopia and five rating dates at Mount Vernon.

'The scion 'Sugar Baby' of grafted plants is abbreviated as 'SB' and the rootstocks of grafted plants are given in parentheses.

${ }^{x}$ The data for each site violated the assumptions of ANOVA and therefore required transformation. PROC RANK in SAS (Version 9.2, SAS Institute, Cary, NC) was used in all cases, and ranked data from each site were compared separately using PROC GLM with $\alpha=0.05$. However, the means presented in the table are non-transformed. Fisher's least significant difference test was used to locate differences in treatment means. Treatment means followed by the same letter within a column are not significantly different at $\alpha=0.05$.

marketable fruit weight per plant were observed among treatments $(P=0.006)$. The overall mean at this site was $12.99 \mathrm{~kg}$, and nongrafted 'Sugar Baby' had a lower yield than all other treatments $(8.11 \mathrm{~kg})$. 'Sugar Baby' grafted onto 'Tetsukabuto' had the highest marketable fruit weight per plant $(16.77 \mathrm{~kg})$ but did not differ from 'Sugar Baby' grafted onto 'Rampart' $(14.14 \mathrm{~kg})$ and 'Marvel' (13.41 kg). At Mount Vernon, nearly mature fruit weight per plant differed among treatments $(P=0.0004)$. 'Sugar Baby' grafted onto 'Tetsukabuto' had a higher yield (15.02 $\mathrm{kg}$ ) than all other treatments. Nongrafted 'Sugar Baby' had a lower yield (4.60 kg) than all other treatments except 'Sugar Baby' grafted onto 'Rampart' (5.49 kg). At Othello, there was no correlation between fruit weight per plant and AUDPC values $\left(r^{2}=-0.43 ; P=\right.$ 0.11 ). However, a negative correlation between these two parameters was observed at both Eltopia $\left(\mathrm{r}^{2}=-0.68 ; P=0.005\right)$ and Mount Vernon $\left(r^{2}=-0.62 ; P=0.01\right)$.

At Othello, there were no differences in number of marketable fruit per plant among treatments $(P=0.48)$ (Table 3$)$. The overall mean at this site was 3.2 and ranged from 3.0 ('Sugar Baby' grafted onto 'Marvel') to 3.5 ('Sugar Baby' grafted onto 'Titan'). At Eltopia, differences in number of marketable fruit per plant were observed among treatments $(P=0.04)$. The overall mean at this site was 2.9. 'Sugar Baby' grafted onto 'Tetsukabuto' had the highest number of fruit per plant (3.7) and differed from all other treatments except 'Sugar Baby' grafted onto 'Rampart' (3.1). Nongrafted 'Sugar Baby' had the lowest number of fruit per plant (2.3). At Mount Vernon, there was no difference in number of fruit per plant among treatments $(P=0.09)$. The overall mean at this site was 1.9 and ranged from 1.4 (nongrafted 'Sugar Baby') to 3.5 ('Sugar Baby' grafted onto 'Tetsukabuto'). Marketable fruit weight differed due to treatment $(P=0.0002)$ but not location, and there was no significant interaction between treatment and location. The overall average marketable fruit weight was $4.2 \mathrm{~kg}$, and was lowest for nongrafted 'Sugar Baby' $(3.6 \mathrm{~kg})$ and greatest for 'Sugar Baby' grafted onto 'Titan' $(4.8 \mathrm{~kg})$ which was statistically equivalent to 'Sugar Baby' grafted onto 'Marvel' (4.7 kg) and 'Sugar Baby' grafted onto 'Tetsukabuto' (4.6 kg).

At Othello, there was no difference in flesh firmness among entries $(P=0.07)$ (Table 4). The overall mean at this site was $3.44 \mathrm{~N}$ and ranged from $2.92 \mathrm{~N}$ (nongrafted 'Sugar Baby') to $4.56 \mathrm{~N}$ ('Sugar Baby' grafted onto 'Marvel'). At Eltopia, flesh firmness differed among treatments $(P=0.01)$. 'Sugar Baby' grafted onto 'Rampart' had the lowest flesh firmness $(3.07 \mathrm{~N})$ but did not differ from nongrafted 'Sugar Baby' (3.14 N). 'Sugar Baby' grafted onto 'Titan' had the highest flesh firmness $(4.37 \mathrm{~N})$ but was not different from 'Sugar Baby' grafted onto 'Marvel' (3.95 N) or 'Tetsukabuto' $(3.79 \mathrm{~N})$. There were no differences in TSS among treatments at Othello or Eltopia $(P=0.18$ and $P=0.32$, respectively). The overall mean at Othello was 9.1\% and ranged from 8.6\% ('Sugar Baby' grafted onto 'Rampart') to 9.5\% ('Sugar Baby' grafted onto 'Titan'). The overall mean at Eltopia was $9.1 \%$ and ranged from $8.7 \%$ ('Sugar Baby' grafted onto 'Tetsukabuto') to 9.5\% ('Sugar Baby' grafted onto 'Titan'). There were no differences in lycopene content among treatments at Othello or Eltopia $(P=$ 0.35 and $P=0.11$, respectively). The overall mean at Othello was $35.58 \mu \mathrm{g} \cdot \mathrm{g}^{-1}$ and ranged from $32.66 \mu \mathrm{g} \cdot \mathrm{g}^{-1}$ ('Sugar Baby' grafted onto 'Tetsukabuto') to $39.93 \mu \mathrm{g} \cdot \mathrm{g}^{-1}$ ('Sugar Baby' grafted onto 'Marvel'). The overall mean at Eltopia was $38.35 \mu \mathrm{g} \cdot \mathrm{g}^{-1}$ and ranged from $34.56 \mu \mathrm{g} \cdot \mathrm{g}^{-1}$ ('Sugar Baby' grafted onto 'Tetsukabuto') to $42.53 \mu \mathrm{g} \cdot \mathrm{g}^{-1}$ ('Sugar Baby' grafted onto 'Marvel').

\section{Discussion}

Previous researchers have found that grafting onto verticillium wilt-tolerant rootstocks can reduce verticillium wilt of watermelon; 

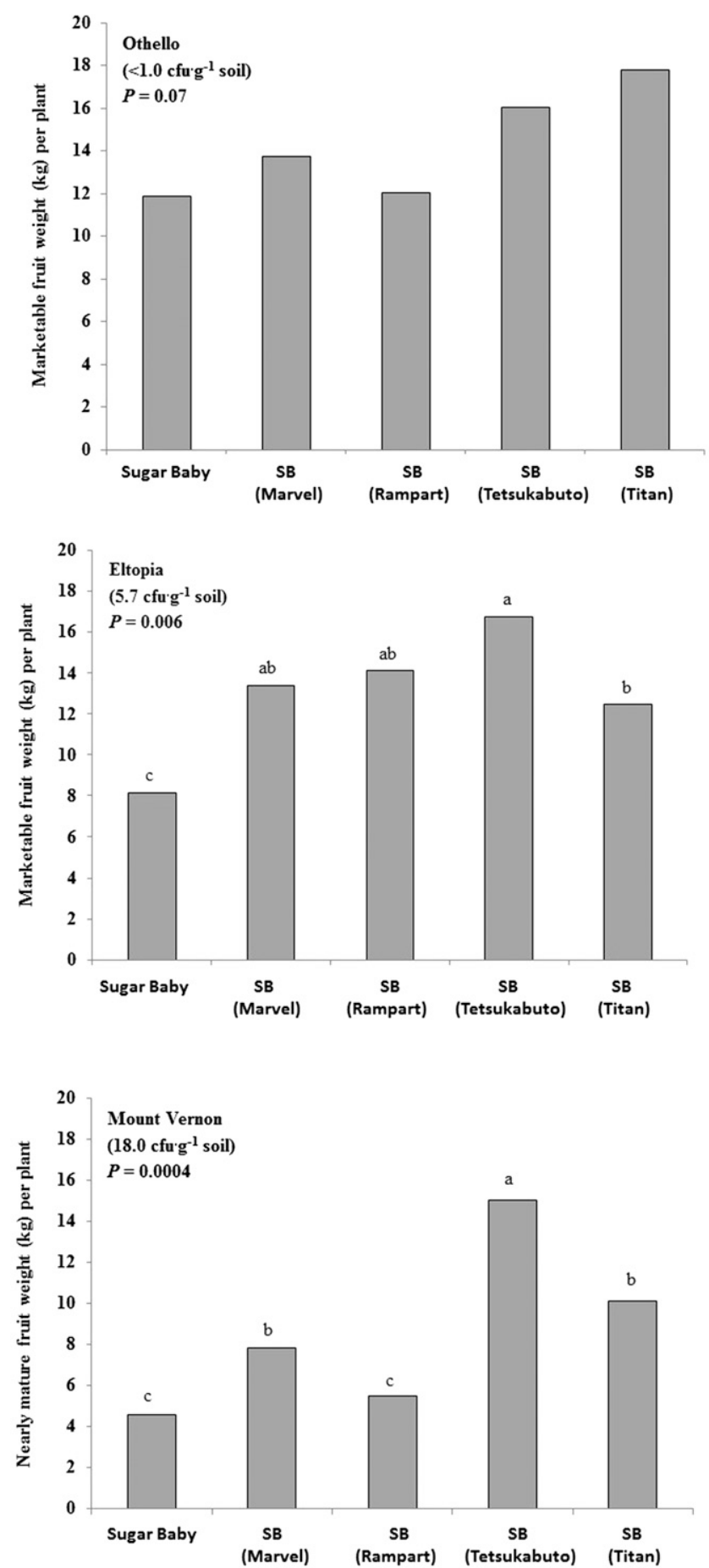

Fig. 1. Marketable fruit weight per plant at Othello and Eltopia, WA, and nearly mature fruit $(>2 \mathrm{~kg})$ weight per plant at Mount Vernon, WA, in 2014. Verticillium wilt susceptible watermelon 'Sugar Baby' was either nongrafted or grafted onto four commercial rootstocks ('Marvel', 'Rampart', 'Tetsukabuto', and 'Titan'). For grafted treatments, 'Sugar Baby' is abbreviated as 'SB' and rootstocks are given in parentheses. The data for Mount Vernon violated the assumptions of ANOVA and therefore required transformation; thus, PROC RANK in SAS (Version 9.2) was used for this site, although the means presented in the table are non-transformed. Data from each site were analyzed separately using PROC GLM with $\alpha=0.05$. Fisher's least significant difference test was used to locate differences in treatment means. For each site, columns with the same letter are not significantly different.

however, these observations are typically dependent on certain factors, including location and rootstock cultivar (Buller et al., 2013; Paplomatas et al., 2002; Paroussi et al., 2007). Similar conclusions can be drawn from the present study in Washington State. At Othello (where the $V$. dahliae soil density was relatively low), grafting did not influence AUDPC values; however, at Eltopia (where the $V$. dahliae soil density was relatively moderate), grafting 'Sugar Baby' onto 'Rampart' and 'Tetsukabuto' reduced AUDPC values. At Mount Vernon (where the $V$. dahliae soil density was relatively high), all grafted treatments had reduced AUDPC values as compared with nongrafted 'Sugar Baby'. Based on pathogen density alone, it would be expected that all treatments at Mount Vernon would have sustained greater severity than counterparts at Othello and Eltopia. Indeed, the AUDPC values for nongrafted 'Sugar Baby' and 'Sugar Baby' grafted onto 'Rampart' were highest at Mount Vernon. However, 'Sugar Baby' grafted onto 'Marvel' and 'Titan' had higher AUDPC values at Eltopia as compared with Mount Vernon, despite the nearly three times greater $V$. dahliae soil density at the latter. Likewise, 'Sugar Baby' grafted onto 'Tetsukabuto' had a higher AUDPC value at Othello than at Mount Vernon. These observations can be partially explained by the climatic differences between these sites. The hot, dry summer conditions at Othello and Eltopia result in relatively high water demand which exacerbates verticillium wilt (Cappaert et al., 1994). Alternatively, the cool, humid summer conditions at Mount Vernon may have "protected" the grafted treatments due to lower water stress. This explanation, however, is not consistent with the verticillium wilt reactions observed for nongrafted 'Sugar Baby' at these sites. The AUDPC values observed for nongrafted 'Sugar Baby' were 154.0, 361.7, and 502.4 at Othello, Eltopia, and Mount Vernon, respectively. Thus, it may be that the susceptibility of 'Sugar. Baby' to $V$. dahliae did not change as a result of the milder Mount Vernon climate. Together, these results suggest that threshold $V$. dahliae soil densities as well as rootstock performance may be regionally specific.

Results from this study demonstrate that yield is impacted by verticillium wilt in Washington. At Eltopia, marketable yield was greatest for 'Sugar Baby' grafted onto 'Tetsukabuto' and 'Rampart', which corresponds to these two treatments having the lowest AUDPC values. Nongrafted 'Sugar Baby' had the lowest marketable yield at Eltopia, reflecting the higher verticillium wilt severity sustained by this treatment. These observations are supported by the negative correlation between yield and AUDPC values at this site. Yield and AUDPC were also negatively correlated at Mount Vernon, where 'Sugar Baby' grafted onto 'Tetsukabuto' had the highest total yield and lowest AUDPC value, and nongrafted 'Sugar Baby' had the lowest total yield and the highest AUDPC value. At Othello, there were no differences in marketable yield or AUDPC values among treatments, and there was no correlation between these two parameters. Based on the findings of this study, grafting can lead to increased yield as compared with non-grafted plants when $V$. dahliae soil populations exceed certain levels, and the severity of verticillium wilt may differ by region because of climate and other factors. A future study focused on the interaction of $V$. dahliae soil densities with contrasting and controlled environmental conditions would 
Table 3. Mean number of watermelon fruit per plant for nongrafted verticillium wilt susceptible 'Sugar Baby' watermelon and 'Sugar Baby' grafted onto the commercial rootstocks 'Marvel', 'Rampart', 'Tetsukabuto', and 'Titan' at Othello, Eltopia, and Mount Vernon, WA, where the Verticillium dahliae populations were <1.0, 5.7, and 18.0 colony-forming units per gram of soil, respectively, in 2014 .

\begin{tabular}{lccc}
\hline & \multicolumn{3}{c}{ Number of fruit per plant $^{z}$} \\
\cline { 2 - 4 } Treatment $^{\mathrm{y}}$ & Othello & Eltopia & Mount Vernon \\
\hline Sugar Baby & 3.2 & $2.3 \mathrm{~b}$ & 1.4 \\
Sugar Baby (Marvel) & 3.0 & $2.8 \mathrm{~b}$ & 2.0 \\
Sugar Baby (Rampart) & 3.1 & $3.1 \mathrm{ab}$ & 1.7 \\
Sugar Baby (Tetsukabuto) & 3.4 & $3.7 \mathrm{a}$ & 3.5 \\
Sugar Baby (Titan) & 3.5 & $2.7 \mathrm{~b}$ & 2.8 \\
$P$ value $^{\mathrm{x}}$ & 0.48 & 0.04 & 0.09 \\
\hline
\end{tabular}

${ }^{\mathrm{z}}$ Only marketable fruit were included at Othello and Eltopia, while at Mount Vernon all nearly mature fruit $(>2 \mathrm{~kg})$ were included.

'The scion cultivar of grafted plants is 'Sugar Baby' and the rootstocks of grafted plants are given in parentheses.

${ }^{\mathrm{x}}$ The data for Mount Vernon violated the assumptions of ANOVA and therefore required transformation; thus, PROC RANK in SAS (Version 9.2, SAS Institute, Cary, NC) was used for this site, although the means presented in the table are non-transformed. Data from each site were analyzed separately using PROC GLM with $\alpha=0.05$. Fisher's least significant difference test was used to locate differences in treatment means. Treatment means followed by the same letter within a column are not significantly different at $\alpha=0.05$.

Table 4. Flesh firmness $(\mathrm{N})$, total soluble solids (TSS, \%), and lycopene content $\left(\mu \mathrm{g} \cdot \mathrm{g}^{-1}\right)$ for nongrafted verticillium wilt-susceptible 'Sugar Baby' watermelon and 'Sugar Baby' grafted onto the commercial rootstocks 'Marvel', 'Rampart', 'Tetsukabuto', and 'Titan' at Othello and Eltopia in 2014.

\begin{tabular}{|c|c|c|c|c|c|c|}
\hline \multirow[b]{2}{*}{ Treatment $^{z}$} & \multicolumn{2}{|c|}{ Firmness $(\mathrm{N})$} & \multicolumn{2}{|c|}{ TSS (\%) } & \multicolumn{2}{|c|}{ Lycopene $\left(\mu g \cdot g^{-1}\right)$} \\
\hline & Othello & $\overline{\text { Eltopia }}$ & Othello & $\overline{\text { Eltopia }}$ & Othello & Eltopia \\
\hline Sugar Baby & 2.92 & $3.14 \mathrm{bc}$ & 9.1 & 9.2 & 33.68 & 39.49 \\
\hline SB (Marvel) & 4.56 & $3.95 \mathrm{a}$ & 9.4 & 9.4 & 39.93 & 42.53 \\
\hline SB (Rampart) & 3.11 & $3.07 \mathrm{c}$ & 8.6 & 8.9 & 32.81 & 35.91 \\
\hline SB (Tetsukabuto) & 3.66 & $3.79 \mathrm{ab}$ & 9.1 & 8.7 & 32.66 & 34.56 \\
\hline SB (Titan) & 2.97 & $4.37 \mathrm{a}$ & 9.5 & 9.5 & 38.82 & 39.26 \\
\hline$P$ value $^{\mathrm{y}}$ & 0.07 & 0.01 & 0.18 & 0.32 & 0.35 & 0.11 \\
\hline
\end{tabular}

${ }^{2}$ The scion 'Sugar Baby' of grafted plants is abbreviated as 'SB' and the rootstocks of grafted plants are given in parentheses.

'Data for each site was analyzed separately using PROC GLM in SAS (Version 9.2) with $\alpha=0.05$. Fisher's least significant difference test was used to locate differences in treatment means. Treatment means followed by the same letter within a column are not significantly different at $\alpha=0.05$.

be useful for assessing suitability of using grafted transplants across diverse production settings.

Fruit quality parameters are important for assessing market acceptability of grafted watermelon. Increased flesh firmness is generally considered a desirable characteristic of watermelon (Davis et al., 2008a). In this study, flesh firmness was increased at Eltopia with the use of 'Marvel' and 'Titan', but not with 'Tetsukabuto' (all of which are Cucurbita hybrids). These findings are consistent with those of Bruton et al. (2009), who reported an increase in flesh firmness as a result of grafting watermelon onto certain hybrid squash rootstocks (RS 1330 and RS 1420) but not others (RS 1332 and RS 1421). 'Sugar Baby' grafted onto 'Rampart' (L. siceraria) did not result in different flesh firmness at Eltopia or Othello as compared with non-grafted 'Sugar Baby'. This finding also is consistent with reported literature, which generally states that Lagenaria rootstocks result in fruit quality similar to nongrafted plants (Bruton et al., 2009; King et al., 2010). The lack of differences in TSS and lycopene content among treatments at either site further suggest that grafting watermelon onto these rootstocks does not have a negative impact on fruit quality.
Based on the findings from this study, any one of the four rootstocks may be appropriate for use in watermelon grafting systems under Washington's diverse growing conditions. 'Tetsukabuto' and 'Rampart' reduced disease severity at Eltopia and Mount Vernon, and also increased marketable yield at Eltopia. 'Titan' and 'Marvel' reduced disease severity at Mount Vernon but not at Eltopia, but did increase yield at both of these sites. In addition, 'Titan' and 'Marvel' increased flesh firmness at Eltopia. These results indicate that grafting watermelon onto such disease-tolerant rootstocks can reduce verticillium wilt severity and increase yield with no negative effects on fruit quality in Washington.

\section{Literature Cited}

Bekhradi, F., A. Kashi, and M. Delshad. 2011 Effect of three cucurbits rootstocks on vegetative and yield of 'Charleston Gray' watermelon. Intl. J. Plant Production 5(2):105-109.

Berlanger, I. and M.L. Powelson. 2000. Verticillium wilt. Online. The Plant Health Instructor. 16 Sept. lessons/fungi/ascomycetes/Pages/VerticilliumWilt. aspx $>$.

Bruton, B.D., W.W. Fish, W. Roberts, and T.W Popham. 2009. The influence of rootstock selection on fruit quality attributes of watermelon. Open Food Sci. J. 3:15-34.

Buller, S., D. Inglis, and C. Miles. 2013. Plant growth, fruit yield and quality, and tolerance to 2013. <http://www.apsnet.org/edcenter/intropp/
Verticillium wilt of grafted watermelon and tomato in field production in the Pacific Northwest. HortScience 48:1-7.

Butterfield, E.J. and J.E. De Vay. 1977. Reassessment of soil assays for Verticillium dahliae. Phytopathology 67:1073-1078.

Cappaert, M.R., M.L. Powelson, N.W. Christensen, W.R. Stevenson, and D.I. Rouse. 1994. Assessment of irrigation as a method of managing potato early dying. Phytopathology 84(8):792800.

Davis, A.R., P. Perkins-Veazie, R. Hassell, A. Levi, S.R. King, and X. Zhang. 2008a. Grafting effects on vegetable quality. HortScience 43:1670-1672.

Davis, A.R., P. Perkins-Veazie, Y. Sakata, S. López-Galarza, J.V. Maroto, S. Lee, Y. Huh, Z. Sun, A. Miguel, S.R. King, R. Cohen, and J. Lee. 2008b. Cucurbit grafting. Crit. Rev. Plant Sci. 27:50-74.

Dung, J.K.S. and J. Weiland. 2014. Verticillium wilt in the Pacific Northwest. PNW Plant disease management handbook. 11 Dec. 2014. $<$ http://pnwhandbooks.org/plantdisease/pathogenarticles/pathogens-common-many-plants/fungi/ verticillium-wilt-pacific-northwest $>$.

Dung, J.K.S. and D.A. Johnson. 2012. Roles of infected seed tubers and soilborne inoculum on Verticillium wilt of 'Russet Burbank' potato. Plant Dis. 96:379-383.

Fradin, E.F. and B.P.H.J. Thomma. 2006. Physiology and molecular aspects of Verticillium wilt diseases caused by $V$. dahliae and $V$. albo-atrum. Mol. Plant Pathol. 7(2):71-86.

King, S.R., A.R. Davis, W. Liu, and A. Levi. 2008. Grafting for disease resistance. HortScience 43:1673-1676.

King, S.R., A.R. Davis, X. Zhang, and K. Crosby. 2010. Genetics, breeding and selection of rootstocks for Solanaceae and Cucurbitaceae. Sci. Hort. 127:106-111.

Kirk, R.E. 1982. Experimental design. 2nd ed. Wadsworth, Belmont, CA.

Klosterman, S.J., Z.K. Atallah, G.E. Vallad, and K.V. Subbarao. 2009. Diversity, pathogenicity, and management of Verticillium species. Annu. Rev. Phytopathol. 47:39-62.

Lee, J., C. Kubota, S.J. Tsao, Z. Bie, P. Hoyos Echevarria, L. Morra, and M. Oda. 2010. Current status of vegetable grafting: Diffusion, grafting techniques, automation. Sci. Hort. 127:93-105.

Lopez-Galarza, S., A. San Bautista, D.M. Perez, A. Miguel, C. Baixauli, B. Pascual, J.V. Maroto, and J.L. Guardiola. 2004. Effects of grafting and cytokinin-induced fruit setting on colour and sugar-content traits in glasshouse-grown triploid watermelon. J. Hort. Sci. Biotechnol. 79 (6):971-976.

Louws, F.J., C.L. Rivard, and C. Kubota. 2010. Grafting fruiting vegetables to manage soilborne pathogens, foliar pathogens, arthropods and weeds. Sci. Hort. 127:127-146.

Miguel, A., J.V. Maroto, A. San Bautista, C. Baixauli, V. Cebolla, B. Pascual, S. Lopez, and J.L. Guardiola. 2004. The grafting of triploid watermelon is an advantageous alternative to soil fumigation by methyl bromide for control of Fusarium wilt. Sci. Hort. 103:9-17.

Miles, C., N. Hesnault, S. Johnson, and P. Kreider. 2013. Vegetable grafting: Watermelon. Wash. State Univ. Ext. Bul. FS100E. 12 Nov. 2014. $<$ http://cru.cahe.wsu.edu/CEPublications/FS100E/ FS100E.pdfs.

Nagata, M. and I. Yamashita. 1992. Simple method for simultaneous determination of chlorophyll and carotenoids in tomato fruit. J. Jpn. Soc. Food Sci. and Tech. 39:925-928. 
Paplomatas, E.J., K. Elena, A. Tsagkarakou, and A. Perdikaris. 2002. Control of Verticillium wilt of tomato and cucurbits through grafting of commercial varieties on resistant rootstocks. Acta Hort. (ISHS) 579:445-449.

Paplomatas, E.J., K. Elena, and A. Tsagkarakou. 2000. Screening tomato and cucurbit rootstocks for resistance to Verticillium dahliae. EPPO Bul. 30:239-242.

Paroussi, G., F. Bletsos, G.A. Bardas, J.A. Kouvelos, and A. Klonari. 2007. Control of Fusarium and Verticillium wilt of watermelon by grafting and its effect on fruit yield and quality. Proc. IIIrd Balkan Symp. on Veg. and Potatoes. Acta Hort. (ISHS) 729:281-285.

Petropoulos, S.A., E.M. Khah, and H.C. Passam. 2012. Evaluation of rootstocks for watermelon grafting with reference to plant development, yield and fruit quality. Intl. J. Plant Production 6:481-492.

Proietti, S., Y. Rouphael, G. Colla, M. Cardarelli, M. De Agazio, M. Zacchini, E. Rea, S. Moscatello, and A. Battistelli. 2008. Fruit quality of miniwatermelon as affected by grafting and irrigation regimes. J. Sci. Food Agr. 88:1107-1114.

Salam, M.A., A.S.M.H. Masum, S.S. Chowdhury, M. Dhar, M.A. Saddeque, and M.R. Islam. 2002. Growth and yield of watermelon as influenced by grafting. Online J. Biol. Sci. 2:298-299.

Sunseri, M. and D.A. Johnson. 2001. Verticillium wilt. Wash. State Univ. Coop. Ext. Bul. EB1908, Pullman, WA.

Taylor, M., B. Bruton, W. Fish, and W. Roberts. 2006. Cost benefit analyses of using grafted watermelons for disease control and the freshcut market, p. 277-285. In: Cucurbitaceae 2006. Asheville, NC.

Tjamos, E.C. 1989. Problems and prospects in controlling Verticillium wilt. NATO ASI Series 28:441-446.

Turhan, A., N. Ozman, H. Kuscu, M.S. Serbeci, and V. Seniz. 2012. Influence of rootstocks on yield and fruit characteristics and quality of watermelon. Hort. Environ. Biotechnol. 53 (4):336-341.

Washington State University. 2014. The Washington agricultural weather network Version 2.0. Prosser, WA. 2 Feb. 2015. <http://weather.wsu. edu/>.

Wimer, J.A., C.A. Miles, and D.A. Inglis. 2014. Evaluation of watermelon rootstocks for resistance to Verticillium wilt in northwestern Washington State. HortScience 49:S195 (abstr.).

Woodward, J.E., T.A. Wheeler, M.G. Cattaneo, S.A. Russell, and T.A. Baughman. 2011. Evaluation of soil fumigants for management of Verticillium wilt of peanut in Texas. Online. Plant Health Prog., doi: 10.1094/PHP-20110323-02-RS.

Yetişir, H., N. Sari, and S. Yücel. 2003. Rootstock resistance to Fusarium wilt and effect on watermelon fruit yield and quality. Phytoparasitica 31(2):163-169. 